\title{
Bioremediation of nitrogen- and phosphorus-polluted aquaculture sediment by utilizing combined immobilized effective microorganisms and sediment aeration technology
}

\author{
Liangkai Wang ${ }^{1,2}$, Xiaohou Shao ${ }^{1,2 *}$, Ming $\mathrm{Xu}^{3}$, Shuang Chen ${ }^{1,2}$ \\ (1. College of Agricultural Engineering, Hohai University, Nanjing 210098, China; \\ 2. Key Laboratory of Efficient Irrigation-Drainage and Agricultural Soil-Water Environment in Southern China of \\ Ministry of Education, Hohai University, Nanjing 210098, China; \\ 3. Jiangsu Provincial Academy of Environment Science, Nanjing 210000, China)
}

\begin{abstract}
The endogenous release of nitrogen and phosphorus from aquaculture sediment can continuously pollute the water quality in aquaculture ponds. In this study, an integrated bioremediation approach that combined effective microorganisms (EM) with aeration techniques was designed to restore contaminated aquaculture sediment. Initially, a set of laboratory-scale experiments was designed to evaluate the feasibility of the technology for the bioremediation of nitrogen and phosphorus. The removal and transformation efficiency indexes of both the overlying water and sediment were measured. From the obtained results, the combination of sediment aeration and immobilized EM significantly improved the nitrogen and phosphorus removal rate from the overlying water and sediment when compared to other methods. Subsequently, a series of field-scale experiments was further implemented to assess the integrated technique in practical applications. In field experiments, the variation in the comprehensive trophic level index (TLI) and sediment biodegradation activities (G value) was used to assess the effect of sediment bioremediation. In pond II which promotes sediment biodegradation, the values of TLI varied from 70.13 to 54.16, and the classification level changed from Hypereutrophic to a Light eutrophic. In addition, the $G$ value increased from $0.98 \mathrm{~kg} /(\mathrm{kg} \cdot \mathrm{h})$ to $2.12 \mathrm{~kg} /(\mathrm{kg} \cdot \mathrm{h})$. The organic matter $(\mathrm{OM})$ and sediment thickness (ST) decreased by $17.4 \mathrm{~g} / \mathrm{kg}$ and $2.3 \mathrm{~cm}$, respectively. The obtained results indicated that the combination of EM and sediment aeration might be feasible and effective for the remediation of nitrogen- and phosphorus-polluted aquaculture sediment.

Keywords: effective microorganisms, immobilization technology, aeration, aquaculture sediment, bioremediation DOI: $10.25165 /$ j.ijabe.20191206.4904
\end{abstract}

Citation: Wang L K, Shao X H, Xu M, Chen S. Bioremediation of nitrogen- and phosphorus-polluted aquaculture sediment by utilizing combined immobilized effective microorganisms and sediment aeration technology. Int J Agric \& Biol Eng, 2019; 12(6): 192-201.

\section{Introduction}

According to statistics, pond culture is one of the major approaches for freshwater aquaculture, which comprises $43.94 \%$ $\left(2.7 \times 10^{6} \mathrm{hm}^{2}\right)$ of the total freshwater area in China ${ }^{[1]}$. To date, more than $80 \%$ of aquaculture has adopted an intensive cultivation pattern to meet the increasing demand, which brings a serious impact of environment ${ }^{[2]}$. Previous studies have shown that a large amount of nutrients (bait, fertilizer, etc.) undecomposed in the production process results in the accumulation of organic matter at the bottom of the pond ${ }^{[3]}$. The internal nitrogen and phosphorous in the sediment are the main sources that responsible for aquaculture eutrophication. Many studies have focused on the remediation of polluted aquaculture environments. Technologies such as the biological aerated filter $^{[4]}$, constructed wetland phytoremediation

Received date: 2019-01-08 Accepted date: 2019-10-16

Biographies: Liangkai Wang, PhD candidate, research interests: agri-biological environmental and energy engineering, Email: wangliangkai93@163.com; Ming $\mathrm{Xu}, \mathrm{PhD}$, Postdoctor, research interests: environment engineering, Email: 108172508@qq.com; Shuang Chen, Master, research interests: agricultural soil and water engineering, Email: 605601766@qq.com.

*Corresponding author: Xiaohou Shao, Professor, research interests: agricultural soil and water engineering. College of Agricultural Engineering, Hohai University, Nanjing 210098, China. Tel: +86-13951005013, Email: shaoxiaohou@163.com. technique ${ }^{[5]}$, and activated carbon materials absorption technique ${ }^{[6]}$ have achieved different degrees of success. However, all the technologies have ignored the remediation of aquaculture sediment, resulting in a lack of control of endogenous pollution. How to effectively degrade contaminants in the sediment has become a vital research topic.

Sediment bioremediation relates to the application of sediment-purifying microorganisms and aeration technology. EM was commonly taken for wastewater treatment, which composed of lactic acid bacteria and yeasts predominate, followed by a low density of photosynthetic bacteria, antinomies and fermenting fungi ${ }^{[7]}$. Over time, these species can efficiently remove internal nitrogen and phosphorus. To meet the demands of in situ bioremediation, a suitable carrier for EM is necessary. As a perfect support material, sludge ceramsite has a porous microstructure with a high surface area, which makes it appropriate as a microbial carrier. Aeration is an effective method for increasing dissolved oxygen levels to fully satisfy the consumption of EM and can also accelerate the oxidation and decomposition of sediment pollutants ${ }^{[8]}$. According to reference ${ }^{[9]}$, aeration accelerates the migration of phosphorus from overlying water to sediment. In addition, dissolved oxygen plays a significant role in nitrification and denitrification, facilitating the removal of internal nitrogen from the sediment ${ }^{[10]}$. However, the effects of different aeration techniques, especially aerating the sediment, have not been fully considered. 
In field aquaculture ponds, water quality is an important factor in assessing the effect of sediment bioremediation techniques. To quantitatively evaluate the trophic status of natural water, the trophic level index (TLI) was designed; TLI is a weighted sum based on five main indexes: Chl-a (chlorophyll a), TP (total phosphorus), TN (total nitrogen), SD (Secchi disk) and $\mathrm{COD}_{\mathrm{Mn}}$ (permanganate index $)^{[11]}$. TLI is a very useful tool to assess pollution levels in a water body and has widespread application in aquatic eutrophication research of the Taihu watershed and Chaohu basin ${ }^{[12,13]}$. However, measuring the water quality indicators is not a comprehensive evaluation for sediment bioremediation. In this research, the key parameters of sediment biodegradability ( $\mathrm{G}$ value) were investigated. The high $G$ value of the sediment is closely related to sediment biodegradation activity, which means that organic matter (OM) can readily decompose $\mathrm{e}^{[14]}$.

Therefore, the objective of this study was to: (1) reveal the sediment nitrogen and phosphorus removal potential of EM and compare the efficacy of immobilized and free-cell EM, (2) evaluate the pollution-removal performance of EM with distinct aeration technologies (water aeration and sediment aeration), and (3) estimate the efficiency of the integrated sediment bioremediation technique in an open system such as a field aquaculture pond. The aim of this study was to verify the feasibility of integrated sediment bioremediation technology for nitrogen and phosphorus removal and provide a new approach for clean and green aquaculture growth.

\section{Materials and methods}

\subsection{Water and sediment sampling}

In this study, water and sediment samples were collected from an aquaculture pond at Baima Lake $\left(33^{\circ} 11^{\prime} 46.91^{\prime \prime} \mathrm{N}\right.$, $\left.119^{\circ} 02^{\prime} 19.55^{\prime \prime} \mathrm{E}\right)$ in Jiangsu, China. Surface sediment samples $(0-10 \mathrm{~cm})$ were collected using a piston column sediment sampler from different sites, and were homogenized and removed the impurities in a tank. The surface overlying water samples (0$30 \mathrm{~cm}$ ) were collected and filtered through a $0.45 \mu \mathrm{m}$ membrane. The water and sediment samples were stored at $4{ }^{\circ} \mathrm{C}$ and treated within $12 \mathrm{~h}$. The characteristics of the overlying water and sediment samples are displayed in Table 6 and Table 7.

\subsection{Preparation of materials}

\subsubsection{Fermentation production of free-cell EM.}

EM bacteria liquids and molasses were purchased from EMRO (Nanjing) Co., LTD. For EM fermentation, 5\% EM bacteria liquids, $5 \%$ molasses and $90 \%$ distilled water were initially mixed to make the EM enrichment culture. Then, the materials for the EM enrichment culture were mixed and fermented by thermostatic shaking (QHZ 98A) at $37^{\circ} \mathrm{C}$ and $150 \mathrm{r} / \mathrm{min}$ until the $\mathrm{pH}$ dropped below $3.5^{[15]}$. The free-cell EM was finally obtained.

\subsubsection{Preparation of carrier pellets.}

Aquaculture pond sediment were the main component of the carrier pellets. Zeolite and sodium humate were used as additives and mixed with aquaculture pond sediment to make the new type biomedium. Three factors were considered in the carrier pellets preparation: weight ratio (WER) of the powdered zeolite: sodium humate: aquaculture pond sediment, calcination temperature, and calcination time.

An orthogonal $\mathrm{L}_{9} 4^{3}$ test was used to analyze the influence of the three factors on the properties of carrier pellets. The Brunauer-Emmett-Teller (BET)-specific surface area was selected as the evaluation index. The orthogonal test design was listed in Table 1. The further orthogonal analysis was listed in Table 2.
Table 1 Factors and levels of the design of orthogonal experiments

\begin{tabular}{ccccc}
\hline $\mathrm{A}$ & $\mathrm{B}$ & $\mathrm{C}$ & $\mathrm{D}$ & $\mathrm{E}$ \\
\hline 1 & $1: 1: 8$ & 700 & 60 & 1 \\
2 & $1.5: 1.5: 7$ & 800 & 80 & 2 \\
3 & $2: 2: 6$ & 900 & 100 & 3 \\
\hline
\end{tabular}

Notes: (A) level; (B) the ratio of raw materials added; (C) calcination temperature, ${ }^{\circ} \mathrm{C}$; (D) calcination time, $\mathrm{h}$; (E) blank columns.

Table 2 Results of orthogonal experiments

\begin{tabular}{cccccc}
\hline $\mathrm{A}$ & $\mathrm{B}$ & $\mathrm{C}$ & $\mathrm{D}$ & $\mathrm{E}$ & $\mathrm{F}$ \\
\hline 1 & $1: 1: 8$ & 700 & 60 & 1 & 34.20 \\
2 & $1: 1: 8$ & 800 & 80 & 2 & 39.10 \\
3 & $1: 1: 8$ & 900 & 100 & 3 & 34.23 \\
4 & $1.5: 1.5: 7$ & 700 & 80 & 3 & 46.15 \\
5 & $1.5: 1.5: 7$ & 800 & 100 & 1 & 47.08 \\
6 & $1.5: 1.5: 7$ & 900 & 60 & 2 & 40.34 \\
7 & $2: 2: 6$ & 700 & 100 & 2 & 28.90 \\
8 & $2: 2: 6$ & 800 & 60 & 3 & 41.65 \\
9 & $2: 2: 6$ & 900 & 80 & 1 & 41.00 \\
$K_{1}$ & 35.843 & 36.417 & 38.730 & 40.760 & \\
$K_{2}$ & 44.523 & 42.610 & 42.083 & 36.113 & \\
$K_{3}$ & 37.183 & 38.523 & 36.737 & 40.677 & \\
$R$ & 8.6800 & 6.1930 & 5.3460 & 4.6470 & \\
\hline
\end{tabular}

Notes: $K_{i}$ here refers to levels of BET-specific surface area and $R$ is the difference between the largest average effect and minimum average effect for every factor. (A) level; (B) the ratio of raw materials added; (C) calcination temperature, ${ }^{\circ} \mathrm{C}$; (D) calcination time, h; (E) blank columns; (F) BET-specific surface area, $\mathrm{m}^{2} / \mathrm{g}$.

The influencing factors on the BET-specific surface area of the carrier pellets were in the following order, from the greatest to the least: ratio of raw materials added $>$ calcination temperature $>$ calcination time. The ratio of raw materials added was found to be decisive part. Some researchers had unveiled that larger BET-specific surface area improved the property of biomass formation ${ }^{[16]}$. In order to get the maximum BET-specific surface area, the optimal preparation conditions of a ratio of raw materials added was $1.5: 1.5: 7$, at a calcination temperature of $800^{\circ} \mathrm{C}$ and a calcination time of $80 \mathrm{~min}$.

The preparation process of the carrier pellets was shown in Figure 1. According to the result of orthogonal test, powdered samples of the zeolite, sodium humate and the aquaculture pond sediment were mixed with a weight ratio of 1.5:1.5:7. Then, the mixture was put into the granulator to obtain an approximately $5 \mathrm{~mm}$ diameter carrier pellet. The sintering process was implemented in a muffle furnace. Before sintering, the carrier pellets were fully dried at $105^{\circ} \mathrm{C}$ for $1 \mathrm{~h}$ to remove moisture, which was beneficial to avoid crazing the surface of the carrier pellets ${ }^{[17]}$, and then sintered at $800^{\circ} \mathrm{C}$ for $80 \mathrm{~min}$. The sintered carrier pellets were gradually cooled to room temperature and the carrier pellets were finally obtained. The physical properties of the carrier pellets are summarized in Table 3 .

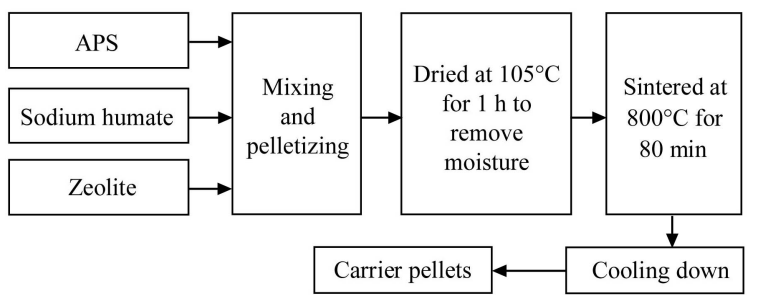

Figure 1 Illustration for the carrier pellets preparation process (APS was the abbreviated notation of aquaculture pond sediment) 
Table 3 Physical properties of the carrier pellets

\begin{tabular}{cccccc}
\hline Properties & $\begin{array}{c}\text { Particle } \\
\text { diameter } \\
/ \mathrm{mm}\end{array}$ & $\begin{array}{c}\text { BET } \\
\text { surface area } \\
/ \mathrm{m}^{2} \cdot \mathrm{kg}^{-1}\end{array}$ & $\begin{array}{c}\text { Bulk } \\
\text { density } \\
/ \mathrm{g} \cdot \mathrm{cm}^{-3}\end{array}$ & $\begin{array}{c}\text { Average pore } \\
\text { diameter } \\
/ \mathrm{nm}\end{array}$ & $\begin{array}{c}\text { Average } \\
\text { pore volume } \\
/ \mathrm{cm}^{3} \cdot \mathrm{g}^{-1}\end{array}$ \\
\hline Carrier pellets & 5 & 48.8128 & $3.6-4.2$ & 7.5462 & 0.3213 \\
\hline
\end{tabular}

\subsubsection{Preparation of immobilized EM}

Secondary fermentation of free-cell EM and carrier pellets was performed. Three liter suspensions of free-cell EM were cultured at room temperature in a sterile five liter beaker that was kept in darkness and continuously aerated, and the $\mathrm{pH}$ was maintained at approximately 7.5. Sterile carrier pellets were added to incubate for $24 \mathrm{~h}$ and then removed. The preparation of immobilized EM was finished when the weight of the carrier pellets was approximately $10 \mathrm{~g}$, and the adsorption quantity of free-cell EM was approximately $5 \mathrm{~mL}$.

\subsection{Experimental design}

\subsubsection{Laboratory experiment}

Customized equipment was utilized in the laboratory for sediment bioremediation. The treatment system was composed of seven independent glasses pieces, each with a size of $400 \mathrm{~mm}$ diameter $\times 600 \mathrm{~mm}$ length. Uniform sediment samples were added into the glasses to a height of $5 \mathrm{~cm}$ and then slowly added the filtered aquaculture pond water to a height of $30 \mathrm{~cm}$. The experimental arrangement with seven different treatments is displayed in Table 4. T1 was static and used as a control, no bioremediation was applied to the sediment. For T2, $20 \mathrm{~g}$ sterile carrier pellets were put into the sediment and stirred well. For T3 and $\mathrm{T} 4,10 \mathrm{~mL}$ of free-cell EM and $20 \mathrm{~g}$ immobilized EM were added to the sediment. T5, T6, and T7 were connected to air pumps. Two air pumps in $\mathrm{T} 5$ and $\mathrm{T} 6$ were used to aerate the sediment. Furthermore, for $\mathrm{T} 5,10 \mathrm{~mL}$ of free-cell EM were added to the sediment and stirred well. For T6 and T7, $20 \mathrm{~g}$ immobilized EM were added to the glasses. The air pump in T7 was used for aerating the overlying water. The aeration mode was performed intermittently by subjecting air pumps to intervals of aeration for $2 \mathrm{~h}$ and paused aeration for $6 \mathrm{~h}$. The aeration began at 0:00, 8:00, and 16:00, respectively. Seven glasses were kept in darkness to avoid photosynthesis, and the surrounding temperature was kept constant at $25^{\circ} \mathrm{C}$ by an air conditioner. The experiment lasted for $15 \mathrm{~d}$. During the course of the experiment, water sample was collected from three different positions in each glasses to monitor relevant indicators on the 1st, 3rd, 5th, 7th, 11th, 13th and 15th days. After sampling, the same amount of aquaculture water was added to the glasses to maintain a water column height of $30 \mathrm{~cm}$. Before and after the test, surface sediment was sampled.

Table 4 Design of different treatments

\begin{tabular}{cccccccc}
\hline Treatment & $\mathrm{T} 1$ & $\mathrm{~T} 2$ & $\mathrm{~T} 3$ & $\mathrm{~T} 4$ & $\mathrm{~T} 5$ & $\mathrm{~T} 6$ & $\mathrm{~T} 7$ \\
\hline $\begin{array}{c}\text { Free-cell } \\
\text { EM/mL }\end{array}$ & $/$ & $/$ & 10 & $/$ & 10 & $/$ & $/$ \\
$\begin{array}{c}\text { Sterile carrier } \\
\text { pellets/g }\end{array}$ & $/$ & 20 & $/$ & $/$ & $/$ & $/$ & $/$ \\
$\begin{array}{c}\text { Immobilized } \\
\text { EM/g }\end{array}$ & $/$ & $/$ & $/$ & 20 & $/$ & 20 & 20 \\
$\begin{array}{c}\text { Aeration } \\
\text { condition }\end{array}$ & $/$ & $/$ & $/$ & $/$ & $\begin{array}{c}\text { sediment } \\
\text { aeration }\end{array}$ & $\begin{array}{c}\text { sediment } \\
\text { aeration }\end{array}$ & $\begin{array}{c}\text { overlying } \\
\text { water aeration }\end{array}$ \\
\hline
\end{tabular}

Note: the dose of the added substance was based on our previous research ${ }^{[18]}$.

2.3.2 Evaluation of bioremediation in a practical aquaculture system

A field experiment was set up for the purpose of verifying sediment bioremediation. Immobilized EM combined with sediment aeration were hypothesized as the best of the sediment bioremediation technologies in aquaculture systems. A preliminary assessment of sediment bioremediation was performed in two similar aquaculture ponds (ponds I, II) at White Horse Lake, where the water quality had experienced serious eutrophication. The two aquaculture ponds were approximately $2 \mathrm{hm}^{2}$ in area, $1 \mathrm{~m}$ in depth and were home to many aquatic animals inhabitants. The sediment bioremediation was applied only in the test pond (pood II) at a rate of $50 \mathrm{~kg} / \mathrm{hm}^{2}$ and provided sediment aeration. Every month from April through October, a water sample $(\sim 500 \mathrm{~mL})$ and sediment sample $(\sim 500 \mathrm{~g})$ were collected from three places in each pond for analysis.

\subsection{Analytical methods}

\subsubsection{Analysis of the overlying water}

The ammonia nitrogen $\left(\mathrm{NH}_{4}{ }^{+}-\mathrm{N}\right)$, total nitrogen $(\mathrm{TN})$, nitrate nitrogen $\left(\mathrm{NO}_{3}{ }^{-} \mathrm{N}\right)$ and total phosphorus (TP) in the overlying water was measured by UV spectrophotometry. The dissolved oxygen (DO) was measured by a portable water analyzer. Transparency was measured by a Secchi disc (SD). The chemical oxygen demand $\left(\mathrm{COD}_{\mathrm{Mn}}\right)$ was detected by the potassium permanganate oxidation method ${ }^{[19]}$. Chl-a was measured by a chlorophyll a fluorescence detector (FuloroQuik, USA). The comprehensive trophic level index (TLI) method was used to estimate the eutrophication level based on Chl-a, TP, TN, SD and $\mathrm{COD}_{\mathrm{Mn}}$, and formulas were calculated as follows ${ }^{[20]}$ :

$$
T L I\left(\sum\right)=\sum_{j=1}^{m} W_{j} \times T L I(j)
$$

where, $\operatorname{TLI}\left(\sum\right)$ is the comprehensive trophic level index; $T L I(j)$ is the trophic level index of parameter $j$; and $W_{j}$ is the corresponding weight of parameter $j$.

$$
W_{j}=\frac{r_{i j}^{2}}{\sum_{j=1}^{m} r_{i j}^{2}}
$$

where $r_{i j}$ is the correlation coefficient between parameter $j$ and reference parameters of Chl-a (Chl-a, 1; TP, 0.84; TN, 0.82; SD, $\left.-0.83 ; \mathrm{COD}_{\mathrm{Mn}}, 0.83\right)$; and $m$ is the number of indictors. The $T L I(j)$ equation was established as follows:

$$
\begin{aligned}
& T L I(C h l-a)=10[2.5+1.086 \ln (C h l-a)] \\
& T L I(T P)=10[9.436+1.624 \ln (T P)] \\
& T L I(T N)=10[5.453+1.694 \ln (T N)] \\
& T L I(S D)=10[5.118-1.94 \ln (S D)] \\
& T L I\left(C O D_{M n}\right)=10\left[0.109+2.661 \ln \left(C O D_{M n}\right)\right]
\end{aligned}
$$

The range of values for $T L I(\Sigma)$ was 0 to 100 ticks; high values represented high eutrophication levels (Table 5).

Table 5 Classification of eutrophication levels

\begin{tabular}{cc}
\hline Comprehensive trophic level index & Level \\
\hline$T L I(\Sigma)<30$ & Oligotrophic \\
$30 \leq T L I(\Sigma) \leq 50$ & Mesotrophic \\
$T L I(\Sigma)>50$ & Eutrophic \\
$50<T L I(\Sigma) \leq 60$ & Light eutrophic \\
$60<T L I(\Sigma) \leq 70$ & Middle eutrophic \\
$T L I(\Sigma)>70$ & Hyper eutrophic \\
\hline
\end{tabular}

\subsubsection{Analysis of the sediment}

After sampling from the glasses, the sediment samples were dried at room temperature, ground in a grinder, and then filtered through a 100 mesh sieve for analyzing the physical and chemical properties. The sediment phosphorus could be divided into total phosphorus (TP), iron/aluminum bound phosphorus (Fe/Al-P), 
inorganic phosphorus (IP), organic phosphorus (OP) and calcium phosphorus (Ca-P) according to the Standard Measurement and Testing (SMT) method ${ }^{[21]}$. The measurement methods of the different forms of $\mathrm{P}$ have been outlined in the research of Ruban et al. ${ }^{[22]}$. The loss on ignition method was adopted to determine the content of organic matter (OM) in sediment. The value of bioremediation of sediment ( $\mathrm{G}$ value) was assayed by the potassium permanganate oxidation method. The sediment biodegradability ( $\mathrm{G}$ value) was tested by accurately weighing $1 \mathrm{~g}$ dried sediment samples in a $1 \mathrm{~L}$ flask, then adding $0.5 \mathrm{~L}$ boiled aquaculture overlying water, and shocking at $6 \mathrm{~h}$ and $30 \mathrm{~min}$ static. The sediment $\mathrm{G}$ value was measured on the basis of the $\mathrm{COD}_{\mathrm{Mn}}$ value of the overlying water before and after the shock ${ }^{[23]}$ :

$$
G=\frac{\left(C_{1}-C_{2}\right) \times V}{10 \times Q \times T}
$$

where, $C_{1}$ and $C_{2}$ are the $\mathrm{COD}_{\mathrm{Mn}}$ value of the water before and after shock, $\mathrm{mg} / \mathrm{L} ; V$ is the volume of the overlying water, $\mathrm{mL} ; Q$ is the weight of the sediment, g; and $T$ is the shock time, h. All the data were expressed as the mean values of three replicates.

\subsection{Statistical analyses}

All of the samples in the experiment were analyzed with three replications. Graphical analyses were implemented using Origin 9.0, whereas the statistical significance, calculated by ANOVA and paired-sample $T$-tests, were determined using SPSS 22.0. Statistics were considered to be significant when $p<0.05$.

\section{Results and discussion}

\subsection{Characteristics of the sampling water and sediment}

The overlying water of the aquaculture pond presented a glossy dark-green color. From Table 6, the water quality of the sampled aquaculture pond was classified as 'hyper eutrophic' according to the trophic level index. For sediment samples, the mud was oily black and mephitic and included undecomposed bait and metabolites of aquatic animals. The results in Table 6 indicated that the initial contents of $\mathrm{TN}, \mathrm{NH}_{4}{ }^{+}-\mathrm{N}$ and $\mathrm{NO}_{3}{ }^{-}-\mathrm{N}$ in sediment were $3.15,0.21$ and $0.01 \mathrm{mg} / \mathrm{g}$, respectively, suggesting that nitrogen mainly existed in the form of organic nitrogen in sediment, which accounted for approximately $90 \%$ of the TN. The original levels of Fe/Al-P, Ca-P, IP, OP, and TP were 138.56, 295.89, 532.54, 98.56 and $730.95 \mathrm{mg} / \mathrm{kg}$, respectively, suggesting that IP was the largest portion in the sediment, accounting for approximately $66 \%$ of the TP. Some existing studies have shown that value of $G$ can be used as an indicator of the bioremediation effect in sediment ${ }^{[24]}$. The low value of $\mathrm{G}(0.98 \mathrm{~kg} /(\mathrm{kg} \cdot \mathrm{h}))$ and high OM $(29.2 \mathrm{~g} / \mathrm{kg})$ of the sediment indicated that the $\mathrm{OM}$ was difficult to mineralize.

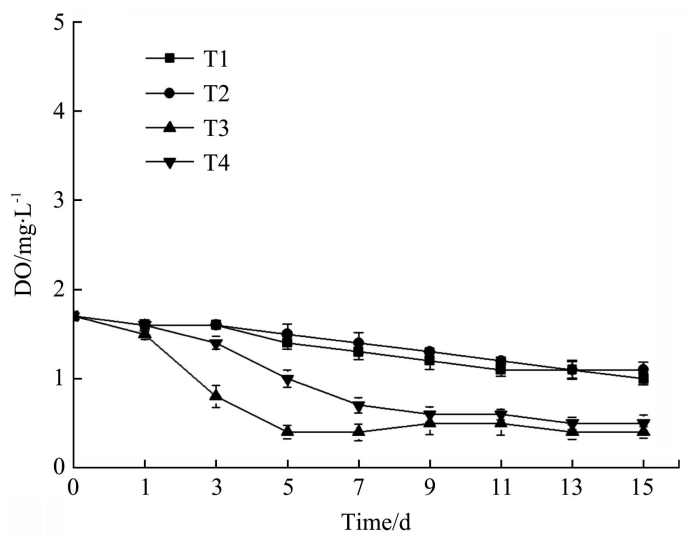

a.
Table 6 Major pollution indicators in overlying water

\begin{tabular}{cccccccc}
\hline $\begin{array}{c}\mathrm{DO} \\
/ \mathrm{mg} \cdot \mathrm{L}^{-1}\end{array}$ & $\begin{array}{c}\mathrm{TN} \\
/ \mathrm{mg} \cdot \mathrm{L}^{-1}\end{array}$ & $\begin{array}{c}\mathrm{NH}_{4}^{+}-\mathrm{N} \\
/ \mathrm{mg} \cdot \mathrm{L}^{-1}\end{array}$ & $\begin{array}{c}\mathrm{NO}_{3}{ }^{-}-\mathrm{N} \\
/ \mathrm{mg} \cdot \mathrm{L}^{-1}\end{array}$ & $\begin{array}{c}\mathrm{TP} \\
/ \mathrm{mg} \cdot \mathrm{L}^{-1}\end{array}$ & $\begin{array}{c}\mathrm{COD}_{\mathrm{Mn}} \\
/ \mathrm{mg} \cdot \mathrm{L}^{-1}\end{array}$ & $\begin{array}{c}\mathrm{Chl}-\mathrm{a} \\
/ \mathrm{mg} \cdot \mathrm{m}^{-3}\end{array}$ & $\begin{array}{c}\mathrm{SD} \\
/ \mathrm{m}\end{array}$ \\
\hline 1.7 & 11.89 & 3.12 & 0.15 & 0.18 & 16.3 & 43.1 & 0.53
\end{tabular}

Table 7 Major pollution indicators in sediment

\begin{tabular}{ccccc}
\hline $\begin{array}{c}\mathrm{TN} \\
/ \mathrm{mg} \cdot \mathrm{g}^{-1}\end{array}$ & $\begin{array}{c}\mathrm{NH}_{4}{ }^{+}-\mathrm{N} \\
/ \mathrm{mg} \cdot \mathrm{g}^{-1}\end{array}$ & $\begin{array}{c}\mathrm{NO}_{3}{ }^{-}-\mathrm{N} \\
/ \mathrm{mg}^{-1}\end{array}$ & $\begin{array}{c}\mathrm{OM} \\
/ \mathrm{mg} \cdot \mathrm{kg}^{-1}\end{array}$ & $\begin{array}{c}\text { Value of G } \\
/ \mathrm{kg} \cdot(\mathrm{kg} \cdot \mathrm{h})^{-1}\end{array}$ \\
\hline 3.15 & 0.21 & 0.01 & 29.2 & 0.98 \\
\hline $\begin{array}{c}\mathrm{Fe} / \mathrm{Al}-\mathrm{P} \\
/ \mathrm{mg} \cdot \mathrm{kg}^{-1}\end{array}$ & $\begin{array}{c}\mathrm{Ca}-\mathrm{P} \\
\mathrm{mg} \cdot \mathrm{kg}^{-1}\end{array}$ & $\begin{array}{c}\mathrm{IP} \\
/ \mathrm{mg} \cdot \mathrm{kg}^{-1}\end{array}$ & $\begin{array}{c}\mathrm{OP} \\
/ \mathrm{mg} \cdot \mathrm{kg}^{-1}\end{array}$ & $\begin{array}{c}\mathrm{TP} \\
/ \mathrm{mg}^{-1} \mathrm{~kg}^{-1}\end{array}$ \\
\hline 138.56 & 295.89 & 536.54 & 98.56 & 710.95 \\
\hline
\end{tabular}

3.2 The effect of sediment bioremediation techniques on $\mathrm{N}$ transformation

3.2.1 Changes in DO in overlying water

The variations of DO in the glasses are shown in Figure 2. In static glasses (T1, T2, T3, T4), DO gradually decreased from 1.7 to $1.0,1.1,0.4$ and $0.5 \mathrm{mg} / \mathrm{L}$, respectively. In addition, the decreased ranges of $\mathrm{T} 3$ and $\mathrm{T} 4$, which contained added $\mathrm{EM}$, were much greater than those of T1 and T2. This result suggested that with the adaptation of EM to the environment, the mineralization of OM was enhanced, continuously accelerated the decline of DO in overlying water. However, during the first $3 \mathrm{~d}$ of aeration, the DO in T5 and T6 sharply decreased and then increased substantially to their maximum values of 4.1 and $4.4 \mathrm{mg} / \mathrm{L}$, respectively, followed by a rapid fall and rise. The DO content in $\mathrm{T} 7$ increased continuously, reached a maximum value of $3.2 \mathrm{mg} / \mathrm{L}$ at $5 \mathrm{~d}$ and then fluctuated between $2.6 \mathrm{mg} / \mathrm{L}$ and $3 \mathrm{mg} / \mathrm{L}$. There was no difference in DO between $\mathrm{T} 5$ and T6, but a significant difference existed between T6 and T7. The DO content in the sediment aeration treatment was even lower than that of the static treatment at the initial stages of the trial, which reflected that the polluted sediment contained a large amount OM and consumed a large amount of DO. After $3 \mathrm{~d}$ of aeration, the DO content in $\mathrm{T} 5$ and $\mathrm{T} 6$ increased quickly, indicating that the $\mathrm{OM}$ was transformed to inorganic matter, resulting in a simultaneous decrease in DO consumption ${ }^{[25]}$. At the beginning of the experiment, the DO content of $\mathrm{T} 7$ exhibited a drastically rising trend, which reflected that the supply of DO remarkably exceeded expenditure under the overlying water aeration condition. However, the DO content of the overlying aeration treatment was lower than that of the sediment aeration treatment at the final stages of the trial. This outcome was consistent with the existing researches, which was due to the undecomposed internal $\mathrm{N}$ in sediment that continuously released pollutants and consumed $\mathrm{DO}^{[26]}$.

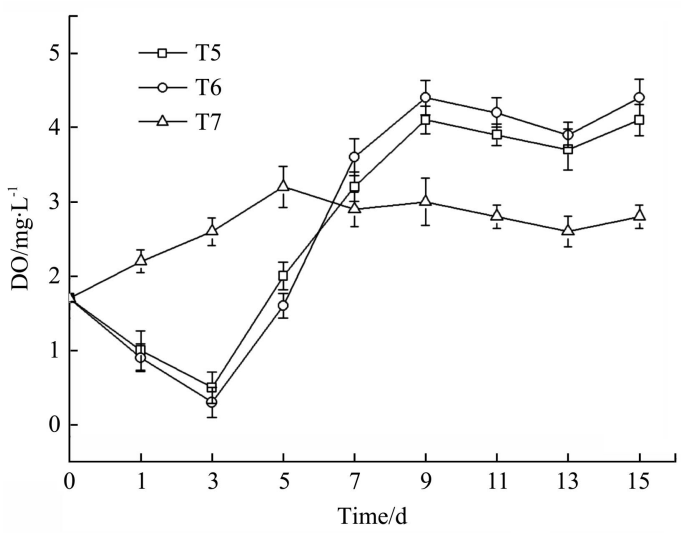

b.

Figure 2 Variations of DO in overlying water under different treatment 
3.2.2 The effect of EM on $\mathrm{N}$ transformation in aquaculture pond sediment

The variations of $\mathrm{NH}_{4}{ }^{+}-\mathrm{N}, \mathrm{NO}_{3}{ }^{-}-\mathrm{N}$ and $\mathrm{TN}$ in the overlying water are shown in Figure 3, Figure 4 and Figure 5, respectively. Under static conditions, the content of $\mathrm{NH}_{4}{ }^{+}-\mathrm{N}$ exhibited a gradual rising trend in $\mathrm{T} 1$ and $\mathrm{T} 2$, indicating that sediment greatly accelerated the endogenous release of nitrogen ${ }^{[27]}$. During the first $3 \mathrm{~d}$, the $\mathrm{NH}_{4}{ }^{+}-\mathrm{N}$ concentration in the overlying water of $\mathrm{T} 3$ and $\mathrm{T} 4$, which contained added EM, were much higher than those in $\mathrm{T} 1$ and T2. This outcome suggested that organic $\mathrm{N}$ was decomposed by EM, released a large amount of $\mathrm{NH}_{4}{ }^{+} \mathrm{N}$ from the sediment ${ }^{[28]}$. However, the $\mathrm{NH}_{4}{ }^{+}-\mathrm{N}$ contents of overlying water in $\mathrm{T} 3$ and $\mathrm{T} 4$ decreased to minimum values of $3.6932 \mathrm{mg} / \mathrm{L}$ and $3.0596 \mathrm{mg} / \mathrm{L}$ at $11 \mathrm{~d}$, respectively, followed by a short increase. The reason could be as follows: (1) the nitrifying bacteria grew, and a part of the $\mathrm{NH}_{4}{ }^{+} \mathrm{N}$ was transformed into $\mathrm{NO}_{3}{ }^{-} \mathrm{N}$, lead to the decrease of $\mathrm{NH}_{4}{ }^{+}-\mathrm{N}^{[29]}$; or (2) the $\mathrm{NH}_{4}{ }^{+}-\mathrm{N}$ began to rise, which was due to the rapid decline of DO in the corresponding treatment. Figure 4 shows that $\mathrm{NO}_{3}{ }^{-} \mathrm{N}$ contents in $\mathrm{T} 1$ and $\mathrm{T} 2$ exhibited a declining

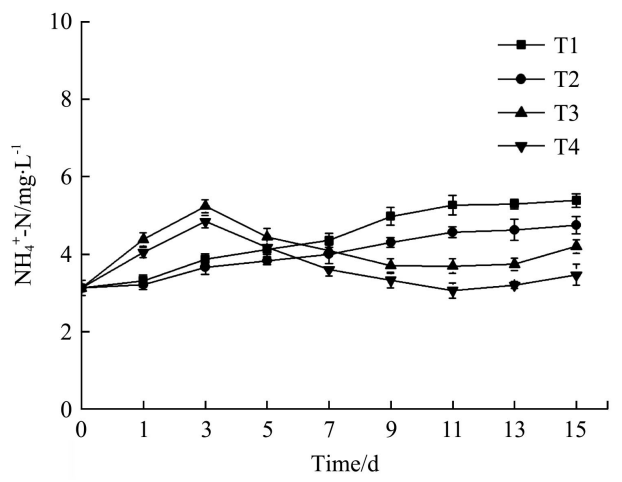

a. trend throughout the experimental period. During the initial period, the content of $\mathrm{NO}_{3}^{-}-\mathrm{N}$ in $\mathrm{T} 3$ and $\mathrm{T} 4$ had no significant change, followed by a remarkable increase to $1.7310 \mathrm{mg} / \mathrm{L}$ and $1.6310 \mathrm{mg} / \mathrm{L}$ at $11 \mathrm{~d}$ and then declined to $1.2891 \mathrm{mg} / \mathrm{L}$ and $1.0893 \mathrm{mg} / \mathrm{L}$, respectively. As shown in Figure 3 and Figure 4, the growth rate of $\mathrm{NH}_{4}{ }^{+}-\mathrm{N}$ was higher than that of $\mathrm{NO}_{3}^{-}-\mathrm{N}$ during the first $3 \mathrm{~d}$, indicating that mineralization was the dominant nitrogen cycle process during the initial incubation stage. However, the content of $\mathrm{NO}_{3}{ }^{-}-\mathrm{N}$ in $\mathrm{T} 3$ and $\mathrm{T} 4$ exhibited a remarkable increasing trend during 3-9 d, which could be the consequence of biological nitrification of $\mathrm{NH}_{4}{ }^{+}-\mathrm{N}^{[30]}$. The $\mathrm{NO}_{3}{ }^{-}-\mathrm{N}$ of both $\mathrm{T} 3$ and $\mathrm{T} 4$ began to decline after $9 \mathrm{~d}$, which was probably because the overlying water was in an anaerobic state with the consumption of oxygen, and the denitrifying bacteria, which included in EM, converted the $\mathrm{NO}_{3}^{-}-\mathrm{N}$ into $\mathrm{NH}_{3}$ and $\mathrm{N}_{2}$ through denitrification and then released it into the atmosphere ${ }^{[31]}$. The TN content in the overlying water exhibited a similar variation trend as $\mathrm{NH}_{4}{ }^{+}-\mathrm{N}$, indicating the concentration of $\mathrm{TN}$ was dominated by the mineralization and transformation of $\mathrm{NH}_{4}^{+}-\mathrm{N}$.

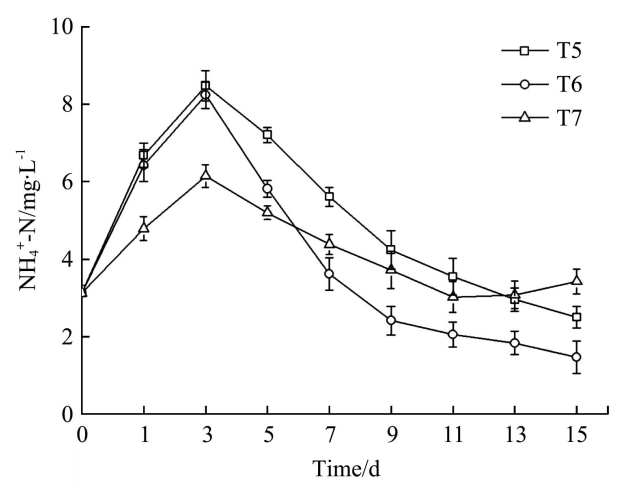

b.

Figure 3 Variations of $\mathrm{NH}_{4}{ }^{+}-\mathrm{N}$ in overlying water under different treatment

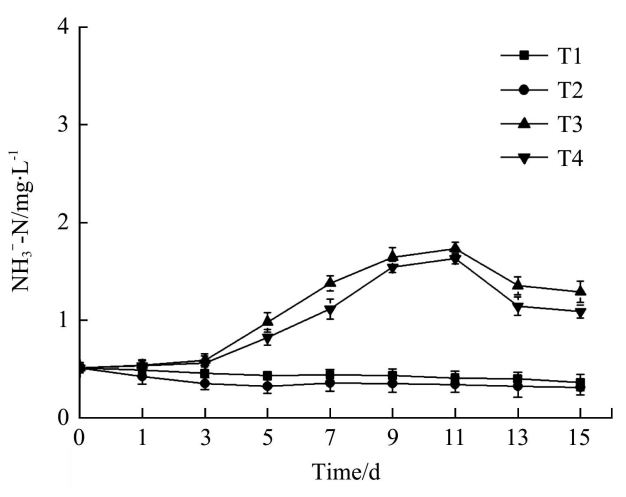

a.

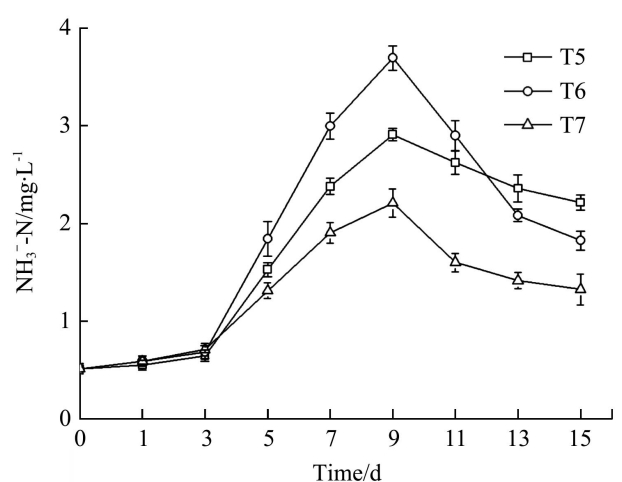

b.

Figure 4 Variations of $\mathrm{NO}_{3}^{-}-\mathrm{N}$ in overlying water under different treatment

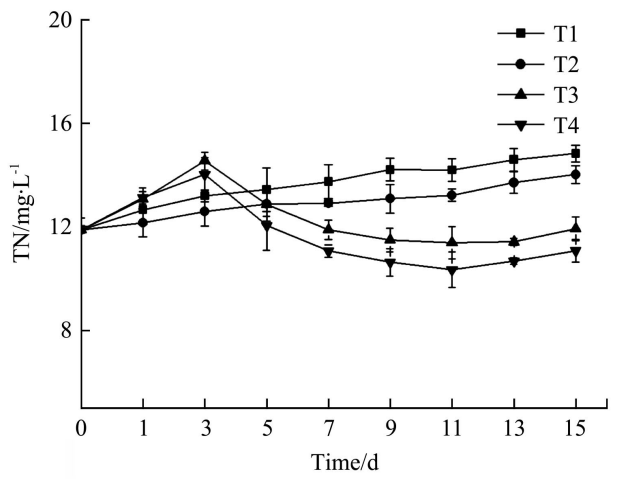

a.

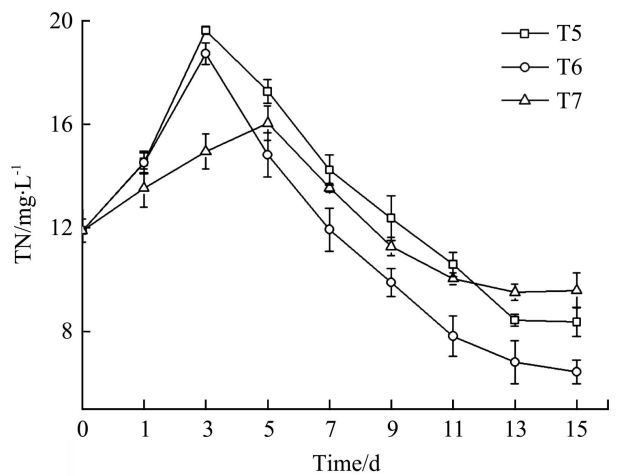

b.

Figure 5 Variations of TN in overlying water under different treatment 


\subsubsection{The invigorating effect of aeration techniques}

Aeration plays a significant role in the bioremediation of sediment, which can strengthen the contact between $\mathrm{OM}$ and microorganisms. The laboratory simulation experiment researched the effects of water aeration (T7) and sediment aeration (T5, T6) based on the addition of EM. Under aeration conditions, the $\mathrm{NH}_{4}{ }^{+}-\mathrm{N}$ content in $\mathrm{T} 5, \mathrm{~T} 6$, and $\mathrm{T} 7$ increased swiftly to 8.4743, 8.2321 and $6.1420 \mathrm{mg} / \mathrm{L}$ and then decreased to $2.4987,1.4662$ and $3.4213 \mathrm{mg} / \mathrm{L}$, respectively. The rising rate of $\mathrm{NH}_{4}{ }^{+}-\mathrm{N}$ in T5 and T6 was particularly faster than that in $\mathrm{T} 7$. It could be deduced that the sediment aeration caused sediment turbulence, strengthening the release of $\mathrm{NH}_{4}{ }^{+} \mathrm{-N}$ from the sediment. However, the overlying water $\mathrm{NH}_{4}{ }^{+}-\mathrm{N}$ content of $\mathrm{T} 7$ was significantly higher than $\mathrm{T} 6$ and $\mathrm{T} 5$ at the end of the experiment. A reasonable explanation is that only the organic nitrogen in surface sediment can be thoroughly decomposed under water aeration conditions. The internal $\mathrm{N}$ in the bottom sediment still released pollutants continuously, causing higher $\mathrm{NH}_{4}{ }^{+} \mathrm{N}$ concentration. Figure 4 shows that the contents of $\mathrm{NO}_{3}{ }^{-} \mathrm{N}$ in the overlying water in $\mathrm{T} 5, \mathrm{~T} 6$ and $\mathrm{T} 7$ slowly decreased at first and then increased dramatically to $2.9078,3.6932$ and $2.2079 \mathrm{mg} / \mathrm{L}$, respectively, followed by a continuous increase until the experiment was over. The capability of nitrification in T5 and T6 was particularly stronger than that in T7. After $3 \mathrm{~d}$, DO started rising, suggesting that the organic nitrogen in the sediment was thoroughly mineralized, and the supply of DO had gradually exceeded consumption under the sediment aeration condition. Meanwhile, the $\mathrm{NO}_{3}^{-}-\mathrm{N}$ of the aeration treatment began to rise and, due to the transformation rate of $\mathrm{NH}_{4}{ }^{+} \mathrm{N}$, exceeded the mineralization rate. Conversely, the decreasing nitration rate and the increasing denitrification rate decreased the content of $\mathrm{NO}_{3}^{-}-\mathrm{N}$. Additionally, the change tendency of TN was the same as that of $\mathrm{NH}_{4}{ }^{+} \mathrm{N}$. From these results, it is concluded that sediment aeration was a more effective treatment for reducing nitrogen loading in sediment compared to water aeration.

Moreover, according to the comparisons of aeration (T5, T6, T7) or static (T3, T4) treatments based on EM technology, the content of $\mathrm{NH}_{4}{ }^{+} \mathrm{N}$ and $\mathrm{TN}$ in overlying showed obvious regulations of $\mathrm{T} 6<\mathrm{T} 5$ $<\mathrm{T} 7<\mathrm{T} 4<\mathrm{T} 3$. Previous studies have reported that aeration technique can make for water purification based on microbial biotechnology by enhancing microbial activity and quantity ${ }^{[32]}$. Microscopic observation validated the validity and reliability of previous studies. Microbes of biofilms in T5, T6 and T7 were richer than those in T3 and T4. However, the morphology of biofilms in T6 maintained stability and integrity, whereas the structure of biofilms in T5 disintegrated. During the aeration period, sediment aeration caused significant fluctuation of sediments in T5 and T6, influencing the biofilm formation to some extent. The attachment of the microorganism on the carrier pellets could prevent biofilms from being broken, which was related to the surface shape and the pore structure of the carrier ${ }^{[33]}$. Figure 6a shows that the microstructure of the surface of the carrier pellets was markedly coarser. From the information shown in Table 3, the BET-specific surface area, average pore volume and average pore diameter of the carrier pellets reached over $48.8128 \mathrm{~m}^{2} / \mathrm{kg}, 0.3213 \mathrm{~cm}^{3} / \mathrm{g}$ and $7.5462 \mathrm{~nm}$, respectively. The rough surface, large BET-specific area and abundant pore structures made it more conducive to attach the EM on the carrier pellets. SEM images in Figure $6 \mathrm{~b}$ show that the biofilm was densely adhered to the surface of the carrier pellets. From the morphology of biofilms in carrier pellets, it can be inferred that immobilized EM were favorable for increasing the capacity of resisting shock under sediment aeration conditions.

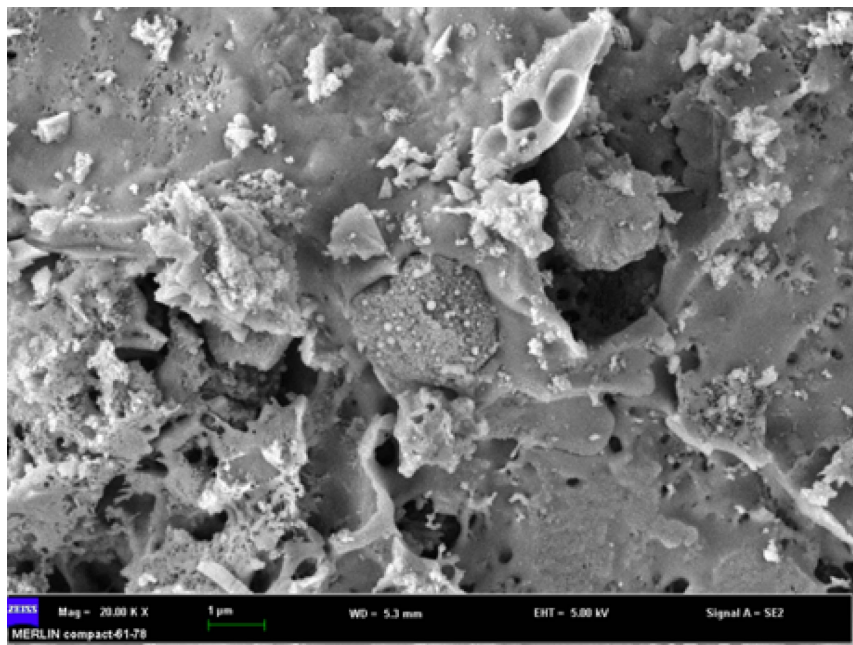

a.

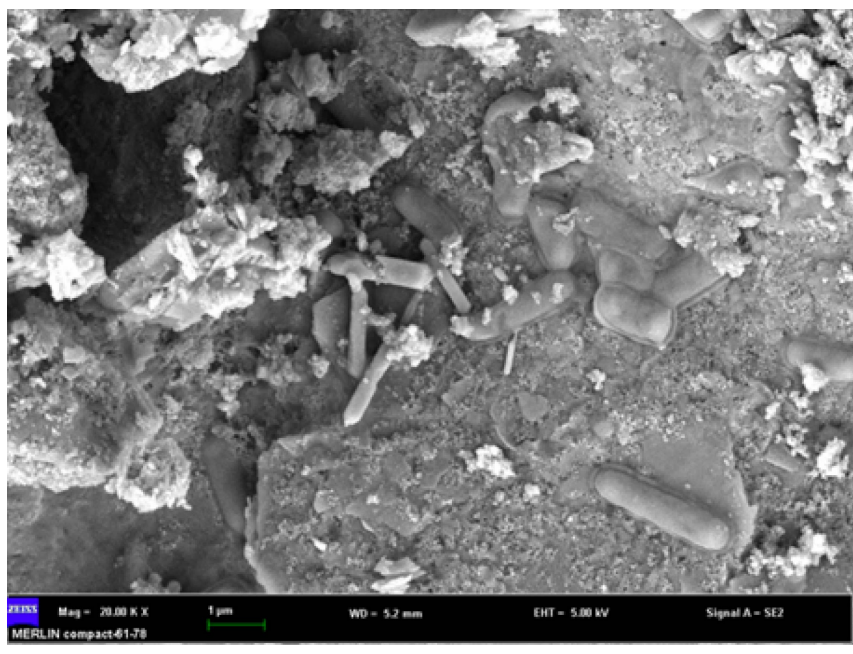

b.

Figure 6 Before and after photos of carrier pellets steeping in EM enrichment culture liquid

\subsection{Effect of sediment bioremediation techniques on $P$ transformation}

3.3.1 The effect of the EM technique on the $\mathrm{P}$ transformation of aquaculture ponds

The variations of TP concentrations in overlying water under static conditions are shown in Figure 7. The TP in T1 gradually increased from $0.1534 \mathrm{mg} / \mathrm{L}$ to $0.6923 \mathrm{mg} / \mathrm{L}$ during the experiment this outcome indicated that sediment greatly promoted the release of endogenous phosphorus at $7 \mathrm{~d}$ of the experiment based on the comparisons of T1 vs. T3 and T2 vs. T4; the TP contents in T3 and T4, which adopted EM, were significantly lower than those in T1 and T2. Previous studies have reported that EM can accumulate a large amount of $P$ beyond their metabolic needs ${ }^{[34]}$. When DO levels were relatively high, EM stored phosphorus sources in the form of polyhydroxyalkanoates (PHAs), which led to a brief drop in the $\mathrm{PO}_{4}{ }^{3}-\mathrm{P}$ concentration in overlying water ${ }^{[35]}$. Thus, it can be inferred that the decrease of TP in T3 and T4 relative to $\mathrm{T} 1$ and $\mathrm{T} 2$ could be attributed to the utilization by EM. However, at the end of the experiment, there were no differences among them, while T1, T3 and T2, T4 had very marked differences. Previous research has shown that under anaerobic conditions, microbial activity is inhibited, polyphosphate (poly-oly-P) degrades and orthophosphate is released $^{[36]}$. The experimental results revealed that under static conditions, the effect of microbial phosphorus removal was not obvious because the DO content in T3 and T4 was continuously consumed by EM. However, according to the 
comparisons of $\mathrm{T} 3$ vs $\mathrm{T} 4$, the immobilized EM had a better purification efficiency, possibly because of the adsorption of carrier pellets.
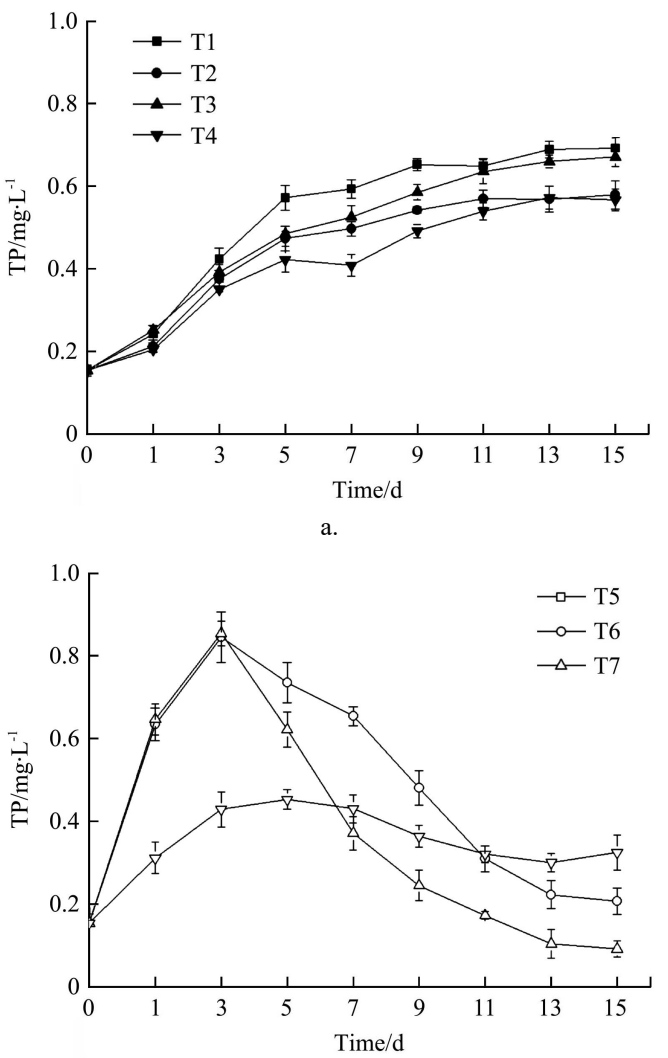

b.

Figure 7 Variations of TP in overlying water under different treatment

\subsubsection{The invigorating effect of aeration techniques}

The role of aeration is mainly to enhance the bioremediation efficiency of EM and to change the redox conditions of the sediment by providing sufficient $\mathrm{DO}^{[37]}$. In this study, the effects of water aeration and sediment aeration on $\mathrm{P}$ transformation were explored and compared. The changing trends of TP in the overlying water under aeration conditions are shown in Figure 7. During the initial aeration stage, the TP concentrations of T5, T6 and T7 increased sharply; this outcome was the result of the turbulence caused by aeration that accelerated the release of TP from the sediment. The variation in sediment aeration treatment was more remarkable. After $3 \mathrm{~d}$, the TP contents of T5 and T6 decreased significantly. The TP content of T5 dropped from $0.8456 \mathrm{mg} / \mathrm{L}$ to $0.2067 \mathrm{mg} / \mathrm{L}$. The TP value of T6 decreased from $0.8545 \mathrm{mg} / \mathrm{L}$ to $0.0909 \mathrm{mg} / \mathrm{L}$. The TP concentration of $\mathrm{T} 7$ increased first, then decreased later, finally stabilized at approximately $0.3241 \mathrm{mg} / \mathrm{L}$. The overlying $\mathrm{TP}$ showed a significant sequence of T3 $<\mathrm{T} 4<\mathrm{T} 7<\mathrm{T} 5<\mathrm{T} 6$. From the results, it could be deduced that the aeration technique strengthened TP purification based on EM in one of two ways: (1) under intermittent aeration conditions, the phosphorusaccumulating bacteria included in EM multiplied and stored orthophosphate as intracellular poly-P, which caused a dramatic drop in $\mathrm{PO}_{4}{ }^{3-}-\mathrm{P}$ contents of the overlying water and led to a high removal efficiency of $\mathrm{TP}^{[38]}$; or (2) the Fe/Al-P content was always affected by DO levels. Under oxidation status, $\mathrm{Fe}^{2+}$ is oxidized to $\mathrm{Fe}^{3+}$. The very reactive $\mathrm{Fe}^{3+}$ form iron hydroxides, which can supply sufficient free sorption sites for the $\mathrm{PO}_{4}{ }^{3-}-\mathrm{P}$ in water and sediment, leading to the formation of stable $\mathrm{Fe}(\mathrm{OOH})-\mathrm{P}$ complexes that caused the decrease in $\mathrm{PO}_{4}{ }^{3-}-\mathrm{P}$ contents in the overlying water ${ }^{[39]}$. One report indicated that inorganic mineral carrier has high adsorption capacity of phosphorus and nitrogen ${ }^{[40]}$. In agreement with previous studies, the final results found that the TP content was significantly lower in T6 than in T5. Relative to T6, T7 had a higher TP concentration in overlying water, indicating that overlying aeration could not remove the internal $\mathrm{P}$ in the bottom sediment thoroughly.

3.3.3 Variations of $\mathrm{P}$ fractions in sediment based on immobilized EM

The sediment $\mathrm{P}$ fractions (TP, Ca-P, Fe/Al-P, OP, and IP) in T4, T6, and T7, which had different aeration measures based on immobilized EM, were measured at the beginning and the end of the experiment. During the experiment, TP increased by $65.03 \mathrm{mg} / \mathrm{kg}$ and $39.28 \mathrm{mg} / \mathrm{kg}$ in $\mathrm{T} 6$ and $\mathrm{T} 7$, respectively, and decreased by $10.39 \mathrm{mg} / \mathrm{kg}$ in T4. The Fe/Al-P content increased by $38.00 \mathrm{mg} / \mathrm{kg}$ and $13.20 \mathrm{mg} / \mathrm{kg}$ in $\mathrm{T} 6$ and $\mathrm{T} 7$, respectively, and decreased by $22.12 \mathrm{mg} / \mathrm{kg}$ in T4. The Ca-P content showed little change in T4, T6, and T7. The IP increased by $42.87 \mathrm{mg} / \mathrm{kg}$ and $36.88 \mathrm{mg} / \mathrm{kg}$ in $\mathrm{T} 6$ and $\mathrm{T} 7$, respectively, and decreased by $12.88 \mathrm{mg} / \mathrm{kg}$ in $\mathrm{T} 4$. The OP increased by $2.00 \mathrm{mg} / \mathrm{kg}$, $28.11 \mathrm{mg} / \mathrm{kg}$ and $19.42 \mathrm{mg} / \mathrm{kg}$ in $\mathrm{T} 4, \mathrm{~T} 6$, and $\mathrm{T} 7$, respectively. The results of the study showed that IP, especially Fe/Al P and Ca-P, comprised the majority of the TP. The concentration of sediment Ca-P showed no obvious difference among the different groups, while Fe/Al-P and OP did. The variations in Fe/Al-P and OP dominated the concentration change in TP. The sediment $\mathrm{Fe} / \mathrm{Al}-\mathrm{P}$ and OP showed obvious regulations of $\mathrm{T} 4<\mathrm{T} 7<\mathrm{T} 6$, and such differences were statistically significant. The sediment oxidation-reduction status was one of the reasons that resulted in variations of Fe/Al-P fraction. Particularly, the T4 sediment aeration caused the disruption of the bottom sediment. The $\mathrm{Fe}^{2+}$ contained in the bottom sediment was oxidized to stable $\mathrm{Fe}^{3+}$, which may have produced more $\mathrm{Fe}^{3+}$ hydroxides than overlying aeration, leading to the increase in sediment Fe/Al-P and TP. In addition, the concentration of OP in T6 was notably higher than in the other treatments. Accordingly, many more microorganisms growth on the sediment surface was observed with sediment aeration conditions than with other conditions. These results suggested that sediment aeration was favorable to the growth of immobilized EM, during which endogenous phosphorus was absorbed to synthesize OP for their breeding colony ${ }^{[41]}$. In contrast, TP, IP, Fe/Al-P and OP in T1 decreased by $26.39 \mathrm{mg} / \mathrm{kg}$, $26.23 \mathrm{mg} / \mathrm{kg}, \quad 18.22 \mathrm{mg} / \mathrm{kg}$ and $2.22 \mathrm{mg} / \mathrm{kg}$, respectively. Compared with T4, there was no difference in OP between $\mathrm{T} 1$ and

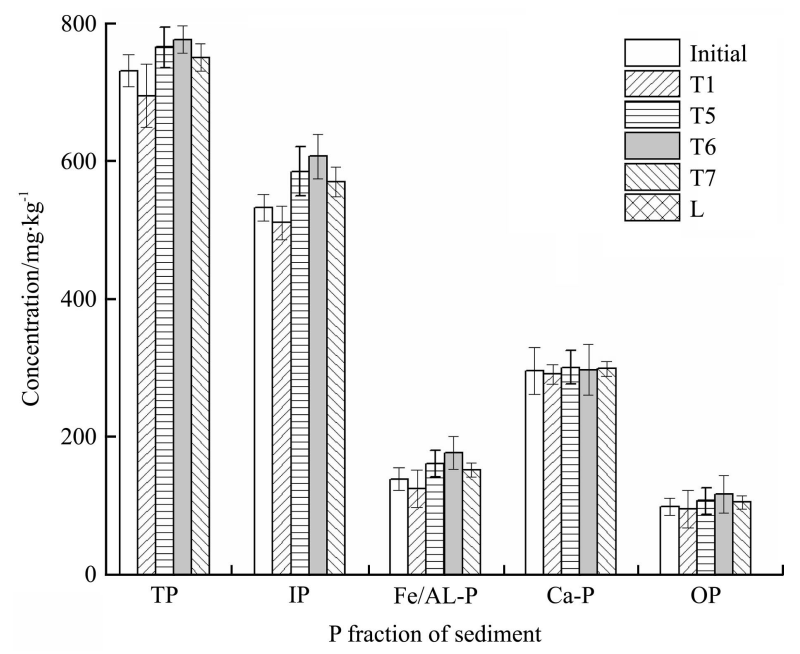

Figure 8 The phosphorus (P) fraction in the sediment after $15 \mathrm{~d}$ 
T4, but the distinction of TP was notable. The results indicated that under an anoxic state, the phosphorus assimilation of EM was unremarkable. The anaerobic conditions accelerated the reduction of $\mathrm{Fe}^{3+}$ and then enhanced the migration of phosphorus from the sediment to the overlying water ${ }^{[42]}$. However, when carrier pellets were placed on top of the contaminated sediment, the migration of internal phosphorus was prevented by physical fixation and absorption. These results were also consistent with the variations of $\mathrm{P}$ in the overlying water.

\subsection{Evaluation of bioremediation in a practical aquaculture system}

The field-scale test was carried out to verify the feasibility of the sediment bioremediation technology. The monitoring results of the water quality and the corresponding sediment indexes are shown in Tables 8 and 9. The SD value indicates the transparency of the water, reflecting the suspended material content. The mean SD value in pond I values decreased from $0.52 \mathrm{~m}$ to $0.45 \mathrm{~m}$. The SD value in pond II appeared to increase from $0.49 \mathrm{~m}$ to $0.86 \mathrm{~m}$. The Chl-a concentration reflects the numbers of phytoplankton. The mean Chl-a values in pond I increased by $3.96 \mathrm{mg} / \mathrm{m}^{3}$. The mean Chl-a values of pond II increased by $18.14 \mathrm{mg} / \mathrm{m}^{3}$. In addition, over the seven-month experiment, the mean values of $\mathrm{COD}_{\mathrm{Mn}}$, TP and TN of the overlying water in pond I increased from $14.2 \mathrm{mg} / \mathrm{L}$, $0.18 \mathrm{mg} / \mathrm{L}$ and $5.21 \mathrm{mg} / \mathrm{L}$ to $20.9 \mathrm{mg} / \mathrm{L}, 0.32 \mathrm{mg} / \mathrm{L}$ and $6.93 \mathrm{mg} / \mathrm{L}$, respectively. Based on the approach of sediment aeration combined with immobilized EM, the concentrations of $\mathrm{COD}_{\mathrm{Mn}}$, TP and $\mathrm{TN}$ in pond II decreased from $14.6 \mathrm{mg} / \mathrm{L}, 0.19 \mathrm{mg} / \mathrm{L}$ and
$5.30 \mathrm{mg} / \mathrm{L}$ to $6.2 \mathrm{mg} / \mathrm{L}, 0.05 \mathrm{mg} / \mathrm{L}$ and $2.05 \mathrm{mg} / \mathrm{L}$, respectively. TLI is usually introduced as an index for describing the eutrophication status of water. In this study, the values of TLI (based on Chl-a, TP, TN, SD and $\mathrm{COD}_{\mathrm{Mn}}$ ) showed variations from 69.60 to 74.88 in pond I and from 70.13 to 54.16 in pond II. At the beginning of the experiment, ponds I and II were in a middle and hyper eutrophic state, respectively. Over the seven-month experiment, the TLI value of pond I markedly increased, and the water quality further deteriorated. Conversely, the range in TLI of pond II showed a change of three trophic levels, from hyper eutrophic to light eutrophic. The TLI values of all aquaculture ponds peaked in August. Temperature is considered to be one of the primary factors determining the seasonal dynamics of eutrophication levels ${ }^{[43]}$. However, the trophic levels of pond II were notably lower than pond I, indicating that the polluted sediment had been gradually restored by the application of immobilized EM combined with sediment aeration. Under sediment bioremediation conditions, the mean sediment $G$ value of pond II increased from $0.98 \mathrm{~kg} /(\mathrm{kg} \cdot \mathrm{h})$ to $2.12 \mathrm{~kg} /(\mathrm{kg} \cdot \mathrm{h})$, while the sediment $\mathrm{G}$ value of pond I without biological repair gradually declined. In general, the high $\mathrm{G}$ value of the sediment suggested a great improvement in sediment biodegradation activity, which is closely linked to the mineralization of $\mathrm{OM}^{[44]}$. The decrease of $\mathrm{OM}$ and sediment thickness (ST) in pond II further substantiated these findings. The results of the present study indicated that the integrated technique had a good sediment biological purification effect, which is applicable to solve the problem of endogenous pollution in aquaculture ponds.

Table 8 Water quality monitoring results in the field experiment

\begin{tabular}{|c|c|c|c|c|c|c|c|c|}
\hline \multirow{2}{*}{ Index } & \multirow{2}{*}{ Pond } & \multicolumn{7}{|c|}{ Month } \\
\hline & & 4 & 5 & 6 & 7 & 8 & 9 & 10 \\
\hline \multirow{2}{*}{$\mathrm{SD} / \mathrm{m}$} & I & $0.52 \pm 0.06$ & $0.53 \pm 0.04$ & $0.50 \pm 0.10$ & $0.48 \pm 0.12$ & $0.54 \pm 0.07$ & $0.49 \pm 0.13$ & $0.45 \pm 0.13$ \\
\hline & II & $0.49 \pm 0.12$ & $0.50 \pm 0.09$ & $0.58 \pm 0.10$ & $0.64 \pm 0.13$ & $0.73 \pm 0.07$ & $0.82 \pm 0.04$ & $0.86 \pm 0.07$ \\
\hline \multirow{2}{*}{$\mathrm{COD}_{\mathrm{Mn}} / \mathrm{mg} \cdot \mathrm{L}^{-1}$} & I & $14.2 \pm 2.2$ & $17.1 \pm 4.1$ & $19.2 \pm 1.7$ & $22.4 \pm 4.6$ & $18.9 \pm 2.6$ & $21.2 \pm 4.7$ & $20.9 \pm 3.9$ \\
\hline & II & $14.6 \pm 1.3$ & $10.2 \pm 3.4$ & $13.1 \pm 4.3$ & $16.4 \pm 2.1$ & $14.3 \pm 1.5$ & $8.3 \pm 3.5$ & $6.2 \pm 2.8$ \\
\hline \multirow{2}{*}{$\mathrm{TP} / \mathrm{mg} \cdot \mathrm{L}^{-1}$} & I & $0.18 \pm 0.07$ & $0.27 \pm 0.12$ & $0.26 \pm 0.21$ & $0.49 \pm 0.21$ & $0.45 \pm 0.08$ & $0.28 \pm 0.31$ & $0.32 \pm 0.07$ \\
\hline & II & $0.19 \pm 0.13$ & $0.14 \pm 0.06$ & $0.21 \pm 0.19$ & $0.23 \pm 0.31$ & $0.15 \pm 0.08$ & $0.09 \pm 0.07$ & $0.05 \pm 0.10$ \\
\hline \multirow{2}{*}{$\mathrm{TN} / \mathrm{mg} \cdot \mathrm{L}^{-1}$} & $\mathrm{I}$ & $5.21 \pm 1.11$ & $4.92 \pm 2.01$ & $6.22 \pm 1.76$ & $6.61 \pm 3.09$ & $6.71 \pm 0.81$ & $7.80 \pm 1.63$ & $6.93 \pm 0.78$ \\
\hline & II & $5.30 \pm 2.10$ & $4.13 \pm 1.54$ & $5.65 \pm 0.92$ & $4.36 \pm 0.76$ & $3.28 \pm 0.59$ & $2.04 \pm 1.02$ & $2.05 \pm 1.93$ \\
\hline \multirow{2}{*}{$\mathrm{Chl}-\mathrm{a} / \mathrm{mg} \cdot \mathrm{m}^{-3}$} & I & $42.13 \pm 7.21$ & $54.87 \pm 6.21$ & $67.41 \pm 7.32$ & $63.42 \pm 3.98$ & $55.67 \pm 14.31$ & $45.21 \pm 11.23$ & $46.09 \pm 7.43$ \\
\hline & II & $41.59 \pm 10.12$ & $30.67 \pm 5.32$ & $45.63 \pm 10.10$ & $50.34 \pm 12.12$ & $40.97 \pm 8.54$ & $30.92 \pm 6.69$ & $23.45 \pm 5.98$ \\
\hline \multirow{2}{*}{$\operatorname{TEL}\left(\sum\right)$} & I & 69.6 & 72.27 & 74.23 & 77.07 & 75.23 & 74.54 & 74.88 \\
\hline & II & 70.13 & 65.74 & 69.77 & 70.29 & 66.39 & 59.51 & 54.16 \\
\hline \multirow{2}{*}{ LEVEL } & I & Middle & Hyper & Hyper & Hyper & Hyper & Hyper & Hyper \\
\hline & II & Hyper & Middle & Middle & Hyper & Middle & Light & Light \\
\hline
\end{tabular}

Table 9 Sediment monitoring results in the field experiment

\begin{tabular}{|c|c|c|c|c|c|c|c|c|}
\hline \multirow{2}{*}{ Sampling point } & \multirow{2}{*}{ Testing index } & \multicolumn{7}{|c|}{ Time } \\
\hline & & 4 & 5 & 6 & 7 & 8 & 9 & 10 \\
\hline \multirow{3}{*}{ Pond I } & $\mathrm{OM} / \mathrm{g} \cdot \mathrm{kg}^{-1}$ & 24.4 & 25.3 & 25.1 & 26.7 & 28.0 & 30.1 & 29.9 \\
\hline & $\mathrm{G} / \mathrm{kg} \cdot(\mathrm{kg} \cdot \mathrm{h})^{-1}$ & 0.89 & 0.84 & 0.91 & 0.97 & 0.85 & 0.78 & 0.81 \\
\hline & $\mathrm{ST} / \mathrm{cm}$ & 20.3 & 20.6 & 20.5 & 20.8 & 21.1 & 21.5 & 21.4 \\
\hline \multirow{3}{*}{ Pond II } & $\mathrm{OM} / \mathrm{g} \cdot \mathrm{kg}^{-1}$ & 25.6 & 28.7 & 20.1 & 24.1 & 16.8 & 12.4 & 8.2 \\
\hline & $\mathrm{G} / \mathrm{kg} \cdot(\mathrm{kg} \cdot \mathrm{h})^{-1}$ & 0.98 & 1.23 & 1.89 & 1.98 & 1.87 & 1.98 & 2.12 \\
\hline & $\mathrm{ST} / \mathrm{cm}$ & 20.1 & 20.1 & 19.8 & 19.5 & 18.9 & 18.0 & 17.8 \\
\hline
\end{tabular}

\section{Conclusions}

In conclusion, the adoption of carrier pellets as a substrate for
EM combined with sediment aeration represents an appropriate measure for the bioremediation of aquaculture sediment in situ. The results verified that aeration increased the oxygen content in 
water and the activity of beneficial microorganisms, as well as their action of absorbing, oxidizing, decomposing and reducing pollutants. In the long run, sediment aeration had a more thoroughly effect on reducing the potential risk of the endogenous release of nitrogen and phosphorus. Meanwhile, upon termination of sediment aeration, the microbial biofilm with immobilized EM were more comprehensive and integrated than free-cell EM, which resulted from the shelter of the carrier pellets. More importantly, due to the high surface reactivity and large surface areas that enhanced the adsorption capacity, the carrier pellets were able to inhibit the release of nitrogen or phosphorus compounds. However, research on the mechanism and function of sediment bioremediation has not yet been conducted. More in-depth studies still need to be conducted with respect to the aeration parameters, material characteristics and performance of EM. Overall, sediment aeration combined with the immobilized EM technique, following reasonable procedures, could significantly improve the restorative effects of aquaculture sediment.

\section{Acknowledgements}

This work was financially supported by the Central University Basic Scientific Research Funding Project (2017B692X14, 2019B45214), the Postgraduate Research \& Practice Innovation Program of Jiangsu Province (KYCX17-0441), the Jiangsu science and technology plan projects (BE2015705, BE2017765), the Water Conservancy Science and Technology Project of Nanjing water (20130317-1), the Nanjing Science and Technology Support Project $(20175044212,201716004)$ and the Nantong Science and Technology Project (MSI2017019-7).

\section{[References]}

[1] Wang Q, Li Z, Gui J F, Liu J, Ye S, Yuan J, et al. Paradigm changes in freshwater aquaculture practices in China: Moving towards achieving environmental integrity and sustainability. Ambio, 2018; 47(4): 410-426.

[2] Ye H, Qiang Zhu J, Li G. Advances in water purification for pond freshwater aquaculture. Advanced Materials research, 2014; 955-959: 3928-3932.

[3] Muhamed A P, Edwin L. Sediment Characteristics of Prawn Aquaculture Systems. Social Science Electronic Publishing, 2017.

[4] Liu H, Zhu L, Tian X, Yin Y. Seasonal variation of bacterial community in biological aerated filter for ammonia removal in drinking water treatment. Water Research, 2017; 123: 668-677.

[5] Hu J, Rui H, Dan Q, Lu X, editors. Study on treatment of aquaculture wastewater using a hybrid constructed wetland. IOP Conf. Ser: Earth Environ. Sci., 2017; 61: 012015

[6] Jegatheesan V, Senaratne N, Steicke C, Kim S H. Powdered activated carbon for fouling reduction of a membrane in a pilot-scale recirculating aquaculture system. Desalination \& Water Treatment, 2009; 5(1-3): 1-5.

[7] Jin M, Wang X W, Gong T S, Gu C Q, Zhang B, Shen Z Q, et al. A novel membrane bioreactor enhanced by effective microorganisms for the treatment of domestic wastewater. Applied Microbiology \& Biotechnology, 2005; 69(2): 229-235.

[8] Zhao Y G, Guo X, She Z, Gao M, Guo L. Effect of gradual-increasing aeration mode in an aerobic tank on nutrients' removal and functional microbial communities. Environmental Technology, 2017; 38(20): 2621.

[9] Doig L E, North R L, Hudson J J, Hewlett C, Lindenschmidt K E, Liber K. Phosphorus release from sediments in a river-valley reservoir in the northern Great Plains of North America. Hydrobiologia, 2016; 787(1): 323-39.

[10] Kim J, Park K, Cho K, Sw, Park T, Bajpai R. Aerobic nitrification-denitrification by heterotrophic Bacillus strains. Bioresource Technology, 2005; 96(17): 1897-1906.

[11] Gao Y J, Cao Y, Zhao Z, Sun C J. Eutrophication control standard for Eastern Lake Region, China basing on the comprehensive trophic level indexes classification. Advanced Materials Research, 2012; 518-523: 2117-2120.
[12] Zhang J, Ni W, Luo Y, Jan Stevenson R, Qi J. Response of freshwater algae to water quality in Qinshan Lake within Taihu Watershed, China. Physics and Chemistry of the Earth, Parts A/B/C, 2011; 36(9-11): 360-365.

[13] Liu Q G, Diao Z G, Sun J Y. Assessment and mechanisms of water eutrophication in Chaohu Lake, China. Advanced Materials Research, 2010; 113-116: 1433-1438.

[14] Yan X, Wang M, Xiaoguang X U, Wang G, Sun H, Yang Y H, et al Migration of carbon, nitrogen and phosphorus during organic matter mineralization in eutrophic lake sediments. Journal of Lake Sciences, 2018; 30(2): 306-313.

[15] Yin C, Shao X H, Wang L, Mao X Y, Lu J, Wang T, et al. Preliminary study on influencing factors of wastewater purification by microbial nano-silica ball. Advanced Materials Research, 2014; 1010-1012: 777-784.

[16] Bao T, Chen T, Wille M-L, Ahmadi N E, Rathnayake S I, Chen D, et al. Synthesis, application and evaluation of non-sintered zeolite porous filter $(\mathrm{ZPF})$ as novel filter media in biological aerated filters (BAFs). Journal of Environmental Chemical Engineering, 2016; 4(3): 3374-3384.

[17] Li S P, Cao X H, Ma X R, Xu J, Dong Y W. Production of lightweight ceramsite from the Yellow River silt and its performance investigation in a biological aerated filer (BAF) reactor. Advanced Materials Research, 2013; 699: 829-834.

[18] Wang L, Shao Y L, Chen L H, Liu J, Shao X H, Wu Q J. Effect of EM techniques on aquaculture wastewater purification. Advanced Materials Research, 2015; 1092-1093: 838-843.

[19] China T S E P A. Water and wastewater monitoring and analysis method. China Environmental Science Press, Beijing. 2002.

[20] Wang J, Fu Z, Qiao H, Liu F. Assessment of eutrophication and water quality in the estuarine area of Lake Wuli, Lake Taihu, China. The Science of the total environment, 2019; 650(Pt 1): 1392-1402.

[21] Ruban V, Brigault S, Demare D, Philippe A M. An investigation of the origin and mobility of phosphorus in freshwater sediments from Bort-Les-Orgues Reservoir, France. Journal of Environmental Monitoring Jem, 1999; 1(4): 403.

[22] Ruban V, López-Sánchez J F, Pardo P, Rauret G, Muntau H, Quevauviller P. Harmonized protocol and certified reference material for the determination of extractable contents of phosphorus in freshwater sediments - A synthesis of recent works. Fresenius Journal of Analytical Chemistry, 2001; 370(2-3): 224-8.

[23] Xie D, Li K, Jiang D. Study on effect of polluted sediments bioremediation on water body bioremediation of polluted urban rivers. Chinese Journal of Environmental Engineering, 2009; 3(8): 1447-53.

[24] Li K, Liu J, Jiang D. Bioremediation and management of the guliao river. Chinese Journal of Environmental Engineering, 2005; 11(6): 742-6.

[25] Su J, Dai M, He B, Wang L, Gan J, Guo X, et al. Tracing the origin of the oxygen-consuming organic matter in the hypoxic zone in a large eutrophic estuary: the lower reach of the Pearl River Estuary, China. Biogeosciences Discussions, 2017; 14(18): 1-24.

[26] Ruan A, He R, Xu S, Lin T. Effect of dissolved oxygen on nitrogen purification of microbial ecosystem in sediments. Journal of Environmental Science and Health, Part A. 2009; 44(4): 397-405.

[27] Wang Z, Bao L I, Liang R. Comparative study on endogenous release of nitrogen and phosphorus in Nansi Lake, China. Acta Scientiae Circumstantiae, 2013; 33(2): 487-93.

[28] Mao X, Shao X, Yin C, Wang L, Chang T, Wang W. Effects of nanosilica immobilised microbes on $\mathrm{NH} 4+-\mathrm{N}$ removal of aquaculture effluent. Materials Research Innovations, 2016; 19(S5): S5-600-S5-5.

[29] Shan H, Obbard J. Ammonia removal from prawn aquaculture water using immobilized nitrifying bacteria. Applied Microbiology \& Biotechnology, 2002; 57(5-6): 791-8.

[30] Zhang F Z, Peng Y, Miao L, Wang Z, Wang S, Li B. A nove simultaneous partial nitrification Anammox and denitrification (SNAD) with intermittent aeration for cost-effective nitrogen removal from mature landfill leachate, Chemical Engineering Journal, 2017; 313: 619-28.

[31] Zielińska M, Rusanowska P, Jarząbek J, Nielsen J L. Community dynamics of denitrifying bacteria in full-scale wastewater treatment plants. Environmental Technology Letters, 2016; 37(18): 1-10.

[32] Wang C, Wu Y, Bai L, Wang C, Jiang H, Wei Z, et al. Intermittent aeration incubation of drinking water treatment residuals for recycling in aquatic environment remediation. Journal of Cleaner Production, 2018; 183: $220-30$.

[33] Bao T, Chen T, Liu H, Chen D, Qing C, Frost R L. Preparation of magnetic porous ceramsite and its application in biological aerated filters. 
Journal of Water Process Engineering, 2014; 4: 185-95.

[34] Mohamad K A, Mohd S Y, Sarah R S, Mohd H Z, Rasyidah A, Mohamad $\mathrm{K}$ A, et al. Total nitrogen and total phosphorus removal from brackish aquaculture wastewater using effective microorganism. American Institute of Physics Conference Series, AIP Conference Proceedings, 2017; 1885: 020127.

[35] Oehmen A, Saunders A M, Vives M T, Yuan Z, Keller J. Competition between polyphosphate and glycogen accumulating organisms in enhanced biological phosphorus removal systems with acetate and propionate as carbon sources. Journal of Biotechnology, 2006; 123(1): 22-32.

[36] Soda S, Heinzle E, Fujita M. Modeling and simulation of competition between two microorganisms for a single inhibitory substrate in a biofilm reactor. Biotechnology \& Bioengineering, 1999; 66(4): 258-264.

[37] Chen J, Lu S, Zhao Y, Wang W, Huang M. Effects of overlying water aeration on phosphorus fractions and alkaline phosphatase activity in surface sediment. Journal of Environmental Sciences, 2011; 23(2): 206-211.

[38] Zeng W, Li B, Yang Y, Wang X, Li L, Peng Y. Impact of nitrite on aerobic phosphorus uptake by poly-phosphate accumulating organisms in enhanced biological phosphorus removal sludges. Bioprocess \& Biosystems Engineering, 2014; 37(2): 277-87.

[39] Kang M, Peng S, Tian Y, Zhang H. Effects of dissolved oxygen and nutrient loading on phosphorus fluxes at the sediment-water interface in the Hai River Estuary, China. Marine Pollution Bulletin. 2018; 130: 132-139.

[40] Yue D T, Yue Q Y, Gao B Y, He H T, Yu H, Sun S L, et al. Preparation of innovative porous ultra-lightweight ceramsite by dehydrated sewage sludge (DSS) and Yellow River sediments (YRS) and its characteristics of ceramsite affected by YRS addition. Applied Mechanics \& Materials, 2013; 357-360: 1446-9.

[41] Zhang Y, Wang C, He F, Liu B, Xu D, Xia S, et al. In-situ adsorption-biological combined technology treating sediment phosphorus in all fractions. Scientific Reports, 2016; 6: 29725.

[42] Yuan C, Rong X, Ying X, Zhang M. Phosphorus fraction and phosphate sorption-release characteristics of the wetland sediments in the Yellow River Delta. Physics \& Chemistry of the Earth Parts A/b/c, 2017; 103: S1474706516302996.

[43] Guo J, Zhang C, Zheng G, Xue J, Zhang L. The establishment of season-specific eutrophication assessment standards for a water-supply reservoir located in Northeast China based on chlorophyll-a levels. Ecological Indicators, 2018; 85: 11-20.

[44] Yu G, Lan Q, Lei H, Tao B, Qiang Y, Zhang M. In situ biochemical technology to control black-odor of polluted sediments in tidal river. Journal of Biotechnology, 2008; 136(4): S665. 